\title{
Energy expenditure in infants in health and disease
}

\author{
ROSS SHEPHERD MD FRACP
}

R SHEPHERD. Energy expenditure in infants in health and disease. Can J Gastroenterol 1997;11(1):101-104. Measurement of energy balance represents a basic theoretical concept in the determination of nutritional and fluid requirements in humans in health and disease. Infants have special nutrient requirements, more limited reserves and relative immaturity of organ function. Energy requirements of infants have been based either retrospectively on intakes required to achieve normal growth or on equations derived from energy expenditure studies performed early this century. Recently, improved techniques for studying resting energy expenditure (REE), total energy expenditure (TEE) and metabolically active body compartments in infants have facilitated more accurate estimates of energy requirements. Such studies indicated that current reference values for energy requirements are overestimates, and that compared with measured values, predicted values vary markedly between the various predictive equations with wide co-efficients of variation. In disease states with altered body composition, such as cystic fibrosis and end-stage liver disease, predictive equations markedly underestimate both energy and fluid requirements. In cystic fibrosis, both TEE and REE are $25 \%$ higher than values in healthy infants. In extrahepatic biliary atresia, energy expenditure per unit body cell mass is markedly elevated, suggesting that this is a catabolic condition in infants. Current estimates of energy and fluid requirements in both health and disease in infants need reappraisal. Bedside and free living energy expenditure methodology should be used to define accurately components of energy requirement in individual infants.

Key Words: Biliary atresia, Cystic fibrosis, Energy expenditure, Infants

\section{Dépense énergétique chez des nourrissons en santé et malades}

RÉSUMÉ : La mesure de l'équilibre énergétique représente un concept théorique fondamental pour la détermination des besoins nutritionnels et liquidiens chez l'humain en santé et chez l'humain malade. Les nourrissons ont des besoins nutritifs particuliers, des réserves moindres et une relative immaturité de leurs fonctions organiques. Le calcul des besoins énergétiques des nourrissons s'est fondé, soit rétrospectivement sur l'apport nécessaire pour l'obtention d'une croissance normale, soit sur des équations tirées d'études sur les dépenses énergétiques effectuées au début du siècle. Récemment, l'amélioration des techniques visant à étudier la dépense énergétique au repos (DÉR) et la dépense énergique totale (DÉT), ainsi que les comportements métaboliquement actifs de l'organisme de nourrissons ont permis le calcul plus précis des besoins énergétiques. De telles études ont révélé que les valeurs de référence actuelles pour ce qui est de l'apport énergétique sont surestimées et en comparaison avec les valeurs mesurées, les valeurs prédites varient considérablement selon les équations de prévisibilité et ce, avec de forts coefficients de variation. En présence de maladie et d'un déséquilibre organique, par exemple en présence de mucoviscidose ou de maladie hépatique terminale, les équations prédictives sous-estiment nettement les besoins énergétiques et liquidiens. Dans la mucoviscidose, les DÉR et les DÉT sont de 25 \% plus élevées que chez le nourrisson sain et cela est principalement dû à des variations génotypiques. Dans l'atrésie biliaire, la dépense énergétique par masse cellulaire unitaire est nettement plus élevée, ce qui donne à penser qu'il s'agit d'une maladie catabolique chez les nourrissons. Les calculs actuels des besoins énergétiques et liquidiens, tant chez le nourrisson en santé que chez le nourrisson malade, doivent être réévalués. Les méthodes portant sur les dépenses énergétiques au repos ou non doivent être utilisées pour définir des composantes plus précises des besoins énergétiques des nourrissons.

This paper was part of a symposium entitled 'Selected topics in pediatric gastroenterology and nutrition' held in October 1995 to honour the academic career of Dr Gordon G Forstner

Department of Gastroenterology, Hepatology and Nutrition, Royal Children's Hospital, and Children's Nutrition Research Centre, Department of Child Health, University of Queensland, Brisbane, Australia

Correspondence: Dr RW Shepherd, Department of Child Health, Royal Children's Hospital, Herston, Brisbane, Queensland, Australia.

Telephone 7-3-365-5476, fax 7-3-253-1981, e-mail r.shepherd@mailbox.uq.edu.au 
Tnfants are entirely dependent on their attendants for food. Each vital function of the growing body has an energy demand that must be met. In this age group - in which there is still relative immaturity of many organ functions - nutrient requirements per unit body weight are greater than at any other time of life and nutrient reserves are more limited. Determination of energy requirement in infants has been based either on the retrospective evaluation of nutrient intakes to achieve normal growth or on equations derived from studies of resting energy expenditure (REE), mostly performed during the first half of this century. These studies have also been the basis for estimating maintenance fluid requirements on the assumption that about $115 \mathrm{~mL}$ of water is lost for every 419 J expended. In 1919 Harris and Benedict (1) formulated their predictive equations based on weight, height and age to the nearest whole year, but very few infants were used in that study. Talbot et al (2) and Talbot (3) generated data by indirect calorimetry that have formed the basis for the 1973 Food and Agriculture Organization/World Health Organization/United Nations University (FAO/ WHO/UNU) recommendations for energy requirements in childhood (4), but their data's reliability was questioned by Schofield (5) who presented new equations derived from REE measurements pooled from a number of studies in limited age categories (infants were in a 'birth to three years' age group).

The data from Talbot (3) formed the theoretical cornerstone for the prediction of maintenance fluid requirements in infants developed by Holliday and Segar (6), and are widely quoted in standard pediatric textbooks (7). These equations have also been used by some groups to evaluate changes in energy expenditure in various disease states $(8,9)$. Their validity is questioned, however, because of recognized alterations in body composition in these states, particularly with respect to the body cell mass which represents the oxygen-exchanging, work-performing, body compartment (10).

The total energy requirements of an infant can be divided into three major components: energy expended in maintaining essential body functions (basal metabolic rate), which includes the synthetic costs of growth; energy used in physical activity and thermogenesis; and energy deposited as new tissue. Attempts to quantify these different components of energy requirement, until fairly recently, have been either of limited accuracy or impossible. Although one can measure basal metabolism by indirect calorimetry, the calorimetric techniques probably are of limited accuracy for infants, and the current equations used are of doubtful validity. The recent extension of the doubly labelled water method into the field of infant nutrition and developments in field techniques such as heart rate monitoring now make the measurement of total energy expenditure (TEE) theoretically achievable. Combining these techniques with the use of dedicated infant indirect calorimetry to measure REE, it is possible to derive estimates for all components of energy requirement. With the advent of noninvasive methods of measuring body cell mass and other body compartments, appropriate reference can be made to energy expenditure per

\section{TABLE 1}

Equations used for estimation of basal energy expenditure in infants

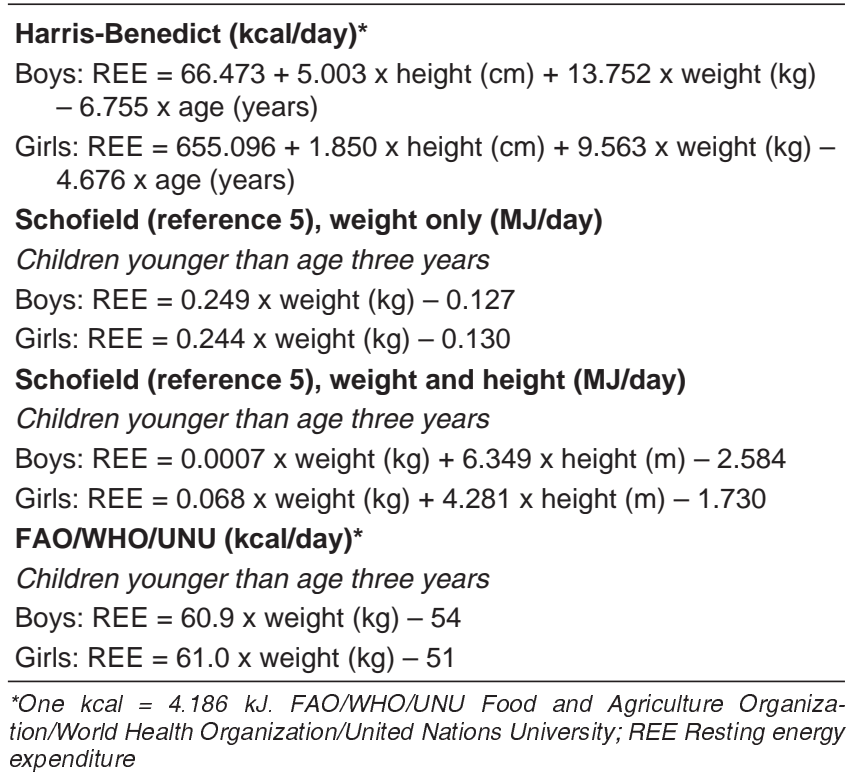

unit of metabolically active cell mass for the study of disease states where altered body composition is present. The body cell mass, which can be measured by total body potassium measurements, appears to be the most appropriate frame of reference against which energy expenditure should be studied in these situations (10). The effect of disease states on resting energy and TEE in infants has been poorly studied.

At the Children's Nutrition Research Centre, Royal Children's Hospital, Brisbane, Australia, we developed techniques for measuring both TEE and REE in relation to noninvasive body composition analysis. Using them, we (11) reviewed the reliability of commonly used predictive equations for estimating energy expenditure in infants in both health and disease, and developed preliminary data for measuring both total and resting body expenditure in infants with specific disease states known to affect body composition, such as cystic fibrosis (CF) $(11,12)$ and end-stage liver disease.

\section{REE IN INFANCY}

Methodology: The author and co-workers have developed a microprocessor-controlled, portable, indirect calorimeter designed primarily for use in spontaneously breathing infants and young children (11). Details of the design have been published previously (11). The device has high resolution accuracy and response time with an overall accuracy of $0.6 \% 2.2 \%$. The associated software makes allowances for temperature, relative humidity and barometric pressure, and enables calculations of the volumes of oxygen consumption and carbon dioxide production to be displayed continuously to define steady state concentrations and to enable later editing for noise from episodes of agitation. Usually two measurements of REE are obtained $3 \mathrm{~h}$ after feeding, separated by a 
$30 \mathrm{~min}$ rest period. There is a $3 \mathrm{~min}$ stabilization period followed by 20 mins of sampling. Measurement is started only after a steady state in the volume of oxygen and carbon dioxide consumption is obtained as defined by variants of less than $5 \%$ for a $30 \mathrm{~s}$ period. Thereafter these two volumes are calculated every $20 \mathrm{~s}$.

REE in healthy infants: The author and colleagues have studied REE in 44 healthy infants aged $0.44 \pm 0.29$ years. Mean \pm SD REE was $0.21 \pm 0.02 \mathrm{MJ} / \mathrm{kg} /$ day for both healthy girls and healthy boys. No significant differences were noted in mean REE for weight between those older versus younger than six months of age, those bottle-fed versus breast-fed and those in a percentile weight for age greater or less than the 90th percentile. Compared with measured values, predicted values from the various equations available (Table 1) varied markedly among equations, generally overestimating REE in these healthy infants (Harris Benedict equation, $182 \% \pm 63 \%$ of measured values; $\mathrm{FAO} / \mathrm{WHO} / \mathrm{UNU}$ equation, 106\% $\pm 14 \%$; Schofield [5] 106\% $\pm 11 \%$ ) (11). Using a generalized linear model of variance, the author and his group observed marked variability in the variance of the four different values for REE (one measured and three predicted) for all subjects combined, as well as for the subsets analyzed (male versus female; age younger or older than six months; and ideal body weight versus below ideal weight). Thus, none of the predictive equations gave an accurate estimate of REE in individual healthy infants. Hence, energy and fluid requirements in individual infants may be wildly overestimated. An example of the measured REE for a healthy $7 \mathrm{~kg}$ male infant versus predicted values is given in Table 2. Review of the derivation of all of the currently used predictive equations calls into question the validity of using them in infants.

REE in infants with disease states - CF: The author and co-workers $(11,12)$ evaluated REE in 20 infants with CF in a cross-sectional study. Mean REE for infants with the $\Delta \mathrm{F} 508 / \Delta \mathrm{F} 508$ genotype was $0.27 \pm 0.03 \mathrm{MJ} / \mathrm{kg} /$ day, which was significantly higher than mean REE of age-, sex- and height-matched controls $(\mathrm{P}<0.001)$. Mean REE for other genotypes was not significantly different from control values. These differences were still found when calculations were corrected for altered body composition, indicating that in the common $\triangle 508 \mathrm{CF}$ genotype, REE is increased per unit metabolically active body cell mass. Previous studies from the author and colleagues (13) on changes in body composition in infants with CF indicated that abnormal body composition with depletion of the body cell mass is evident in most $\mathrm{CF}$ infants following diagnosis by neonatal screening. There is some catch-up growth by six to 12 months, which is incomplete in some individuals at one year of age, with persistence of body fat depletion. These dynamic changes in body composition, particularly those of the metabolically active cell mass, need to be considered when assessing energy requirements in CF infants. Predictive equations grossly underestimate the true energy requirements, as seen by the example in Table 3. These findings have important clinical implications with respect to early nutritional management of CF.
TABLE 2

Estimated versus measured energy and fluid requirements in a healthy infant age seven months, weight $7 \mathrm{~kg}$

\begin{tabular}{lcc}
\hline & Estimated (WHO) & Measured $^{*}$ \\
\hline Resting energy expenditure (MJ/day) & 1.54 & 1.43 \\
Total energy expenditure (MJ/day) & 2.73 & 2.31 \\
Basal fluid (mL/day) & 427 & 385 \\
Total fluid (mL/day) & 735 & 637 \\
\hline
\end{tabular}

${ }^{*}$ Resting energy expenditure was measured by indirect calorimetry and total energy expenditure by doubly labelled water. WHO World Health Organization

\section{TABLE 3}

Estimated versus measured energy and fluid requirements in an infant with cystic fibrosis age eight months, weight $7 \mathrm{~kg}$

\begin{tabular}{lcc}
\hline & Estimated (WHO) & Measured $^{*}$ \\
\hline Resting energy expenditure (MJ/day) & 1.54 & 1.82 \\
Total energy expenditure (MJ/day) & 2.73 & 3.71 \\
Basal fluid (mL/day) & 427 & 504 \\
Total fluid (mL/day) & 735 & 1029 \\
\hline
\end{tabular}

${ }^{*}$ Resting energy expenditure was measured by indirect calorimetry and total energy expenditure by doubly labelled water. WHO World Health Organization

End-stage liver disease: The author and co-workers evaluated REE in 18 infants with chronic liver disease due to extrahepatic biliary atresia following a failed Kasai portoenterostomy operation. All infants were on a liver transplant waiting list and had severe protein energy undernutrition with marked alterations in body composition. In these infants, the absolute value of REE was significantly greater $(2.9 \pm 0.3 \mathrm{MJ} /$ day $)$ than that in matched healthy children $(2.1 \pm 0.2 \mathrm{MJ} /$ day $)(\mathrm{P}<0.05)$. When differences in body composition were considered, normalizing for body cell mass, total body potassium was $0.21 \pm 0.02 \mathrm{MJ} / \mathrm{g}$ in these infants versus $0.16 \pm 0.02 \mathrm{MJ} / \mathrm{g}$ in controls $(\mathrm{P}<0.02)$.

The REE of infants with chronic liver disease was significantly greater than that predicted using equations from WHO (129\%) and Schofield (5) (130\%) ( $<<0.005)$. Thus, end-stage liver disease, at least in this age group, is a catabolic disease. This could be explained on the basis of depleted or altered availability of glycogen and/or altered intermediary nitrogen metabolism, particularly during fasting.

\section{TEE IN INFANCY}

Knowledge of TEE is of major biological and clinical importance, particularly during infancy. TEE can provide information for estimation of recommended daily amounts of food energy and is essential for the design of artificial infant feeds and the provision of energy requirements for disease states. Established techniques for measuring TEE using direct calorimetry are unacceptable in infancy because they require that the subject be isolated for long periods.

TEE methodology: An important development in the study of human energy metabolism has been the use and validation of the doubly labelled water technique. The method has been applied in infancy in both health $(14)$ and disease $(15,16)$. 


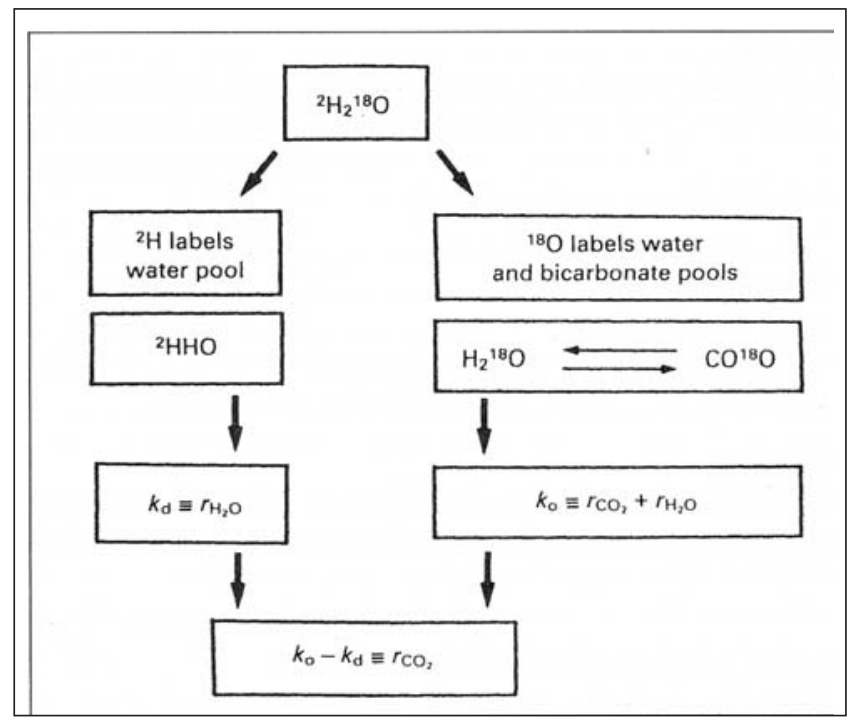

Figure 1) Schematic explanation of the doubly labelled water method, where $k$ is a rate constant for isotope disappearance, $r$ is a production rate, and subscripts $\mathrm{d}$ and $o$ refer to ${ }^{2} \mathrm{H}$ and ${ }^{18} \mathrm{O}$, respectively

Figure 1 illustrates the principle behind the doubly labelled water method. An accurately weighed oral dose of water labelled with the stable isotopes ${ }^{2} \mathrm{H}$ and ${ }^{18} \mathrm{O}$ is administered. The ${ }^{2} \mathrm{H}$ labels the body's water pool and the ${ }^{18} \mathrm{O}$ labels both water and bicarbonate pools, which are in rapid equilibrium through the carbonic anhydrase reaction. The turnover rates of the two isotopes are measured by analysis of serial urine samples collected over five to seven days. The ${ }^{2} \mathrm{H}$ rate constant represents water turnover and the ${ }^{18} \mathrm{O}$ rate constant represents water plus carbon dioxide turnover, from which carbon dioxide production can be derived by determining the difference. Energy expenditure is calculated from carbon dioxide production using indirect calorimetric calculations that require an estimate of the mean respiratory quotient over the entire measurement period.

TEE in healthy infants: Davies et al (14) prospectively evaluated 41 normal, full-term infants at 1.5 , three and six

\section{REFERENCES}

1. Harris J, Benedict FA. A Biometric Study of Basal Metabolism in Man [Publication No 279]. Washington: Carnegie Institute of Washington, 1919.

2. Talbot F, Wilson E, Worester J. Basal metabolism of girls: physiological background and application of standards. Am J Dis Child 1937;53:274-7.

3. Talbot FB. Basal metabolism in children. In: Brennemann G, ed. Brennemann's Practice of Pediatrics. Maryland: Prior, 1949.

4. World Health Organization. Energy and protein requirements: report of a joint $\mathrm{FAO} / \mathrm{WHO} / \mathrm{UNU}$ expert consultation [WHO Technical Report Series No 724]. Geneva: World Health Organization, 1985.

5. Schofield C. Predicting basal metabolic rate, new standards and review of previous work. Hum Nutr Clin Nutr 1985;39C(Suppl 1):5-42.

6. Holliday MA, Segar WE. The maintenance need for water in parenteral fluid therapy. Pediatrics 1957,19:823-32.

7. Adelman RD, Solhung MJ. Fluid therapy. In: Behrman RE, Kliegman RM, Arvin AM, eds. Nelson Textbook of Pediatrics, 15th edn. Philadelphia: Saunders, 1996:206-10.

8. Tilden S, Watkins S, Thong T, Jeevanandam M. Measured energy expenditure in pediatric intensive care patients. Am J Dis Child 1989;143:490-2.

9. Vaisman N, Pencharz P, Corey M, et al. Energy expenditure of patients with cystic fibrosis. J Pediatr 1987;111:496-500. months of age. Mean TEE was $0.27,0.28$ and $0.33 \mathrm{MJ} / \mathrm{kg} / \mathrm{day}$, respectively. These authors developed percentiles for TEE in early infancy and suggested that the current dietary guidelines for healthy infants may be a prescription for overfeeding (17) based on estimations of predictive equations.

TEE in infants and disease states: Only limited studies of TEE have been done in infants with altered body composition and disease states. The author and his group studied CF infants and children younger than two years of age without significant lung disease and found that TEE was 25\% higher than in healthy infants (15). These earlier studies were not controlled for alterations in body composition, although the CF group as a whole had reduced metabolically active cell mass compared with the control group, which tended to outweigh the possible contribution of altered body compartments. These studies, in conjunction with the REE studies indicated earlier, suggest that CF infants are unable to compensate for the increased REE by a reduction in activities, which accounts for the difference between TEE and REE including, in infants, the synthetic cost of growth, energy used in physical activity, thermogenesis and energy deposited as new tissue.

\section{CONCLUSIONS}

Current estimates and recommended energy and fluid requirements in infants in both health and disease need reappraisal. Current predictive equations tend to overestimate energy expenditure in healthy infants and underestimate energy expenditure in infants with CF and liver disease. The acquisition of bedside energy expenditure methodology is needed to define accurately all components of energy requirement in individual infants. In particular, measurement of TEE by the doubly labelled water technique and its validity in infants is superior to any other available method based on measurement of either intake or expenditure. The 1985 FAO/WHO/UNU Report (4) stated that, "in principle it would be desirable to determine the requirements of children in the same way as for adults, from measurements of energy expenditure". This now appears to be possible.

10. Kinney JM, Lister J, Moore FD. Relationship of energy expenditure to total exchangable potassium. Ann NY Acad Sci 1963;110:711-22.

11. Thomson MA, Buccolo S, Quirk P, Shepherd RW. Measured versus predicted resting energy expenditure in infants: a need for reappraisal. J Pediatr 1995;126:21-7.

12. Thomson MA, Wilmott RW, Wainwright C, Masters B, Francis PJ, Shepherd RW. Resting energy expenditure, pulmonary inflammation and genotype in the early course of cystic fibrosis. Pediatr Pulmol 1995;2(Suppl 12):261. (Abst)

13. Greer R, Shepherd RW, Cleghorn GJ, Bowling FG, Holt T. Evaluation of growth in changes in body composition following neonatal diagnosis of cystic fibrosis. J Pediatr Gastroenterol Nutr 1991;13:52-8.

14. Davies PSW, Ewing G, Lucas A. Energy expenditure in early infancy. Br J Nutr 1989;62:621-9.

15. Shepherd RW, Holt TL, Vasques-Velasquez L, Coward WA, Prentice A, Lucas A. Increased energy expenditure in young children with cystic fibrosis. Lancet 1988;i:1300-3.

16. Vasques-Velasquez L. Energy expenditure and physical activity of malnourished Gambian infants. Proc Nutr Soc 1988;47:233-9.

17. Prentice A, Lucas A, Vasques-Velasquez L, Davies PS, Whiteheard RG. Are current dietary guidelines for young children a prescription for over-feeding? Lancet 1988;ii:1066-9. 


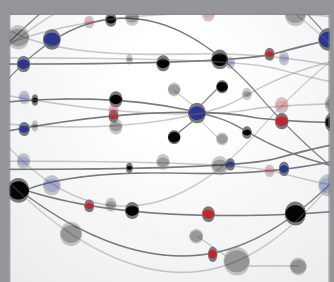

The Scientific World Journal
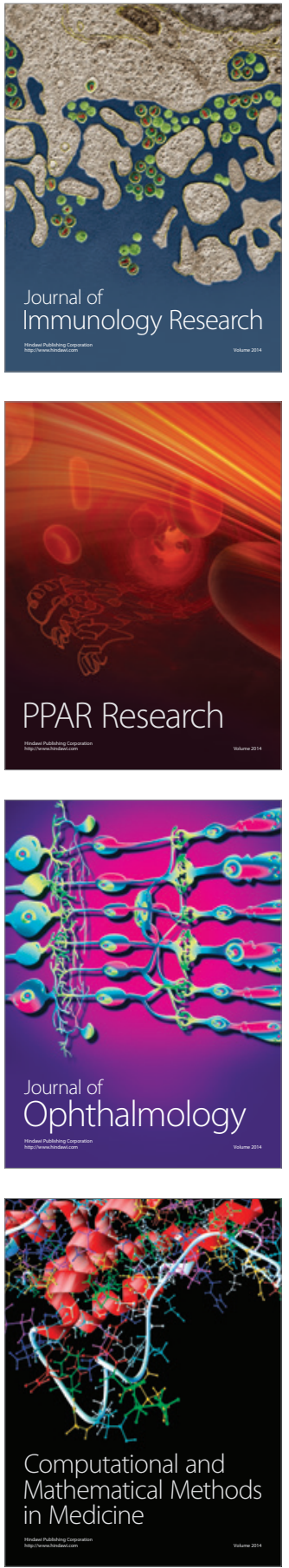

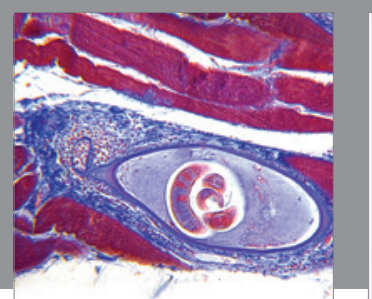

Gastroenterology Research and Practice

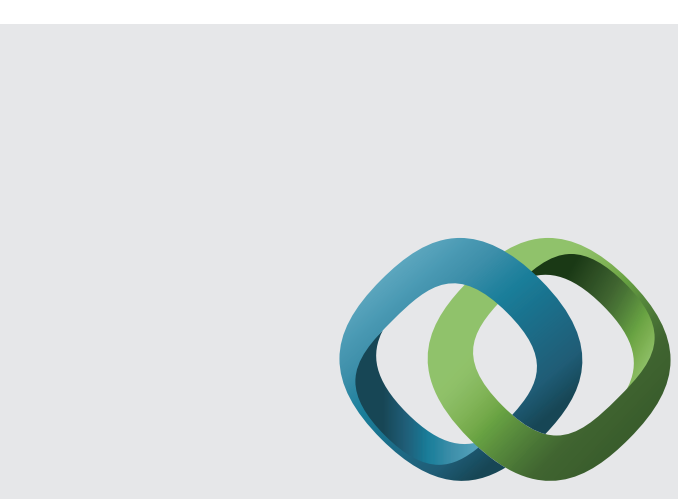

\section{Hindawi}

Submit your manuscripts at

http://www.hindawi.com
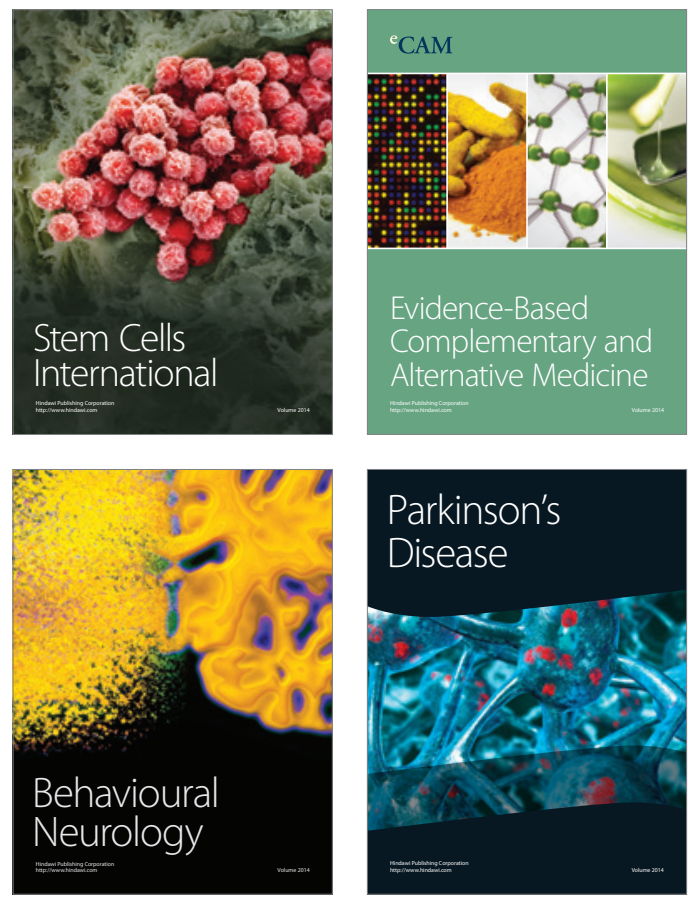
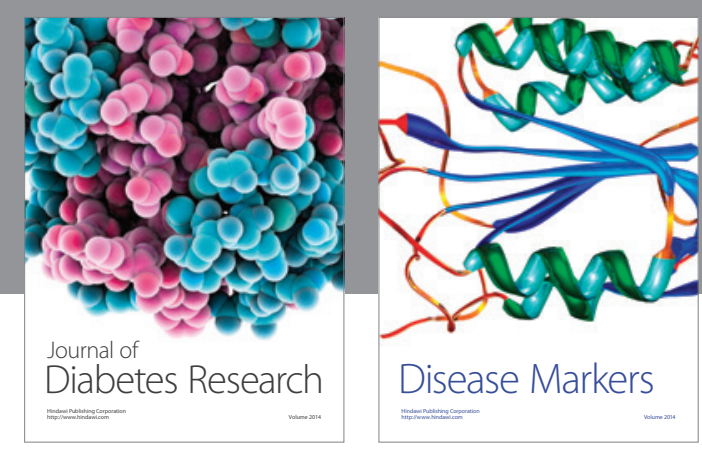

Disease Markers
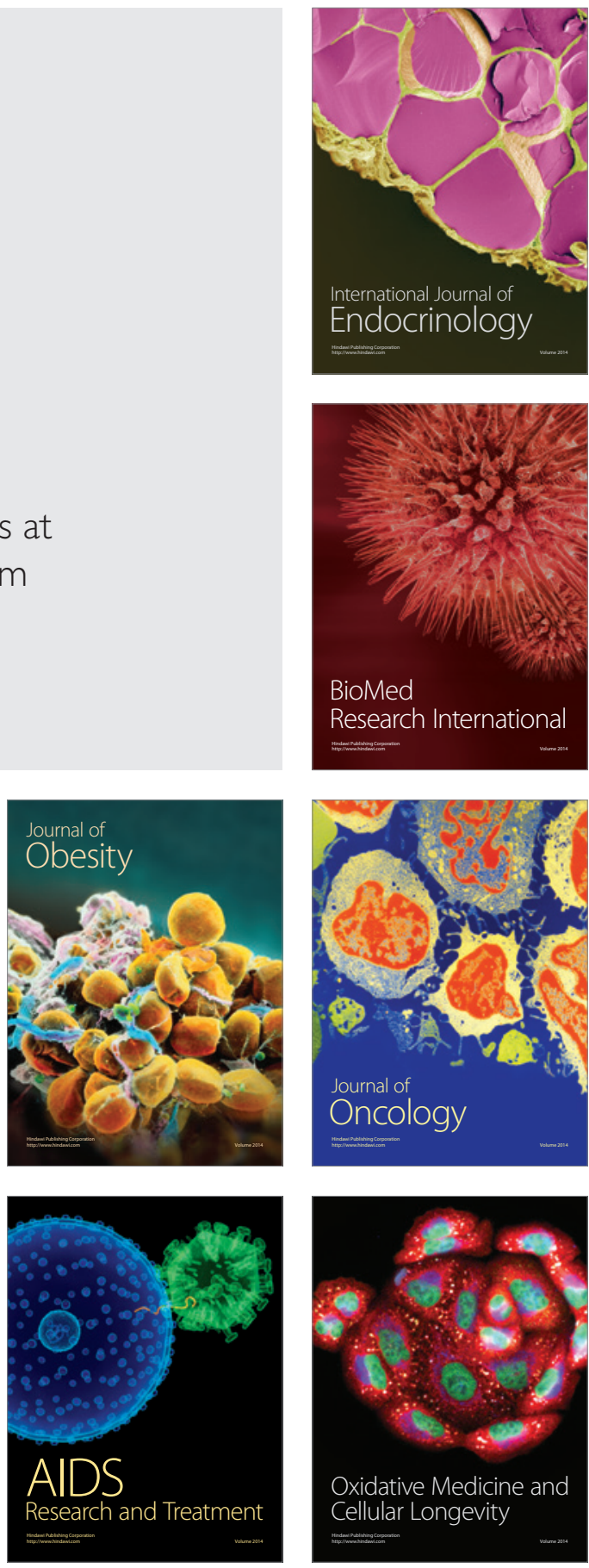